\title{
PREPAREDNESS AND RESPONSE OF PAKISTAN FOR CORONA VIRUS DISEASE 2019: GAPS AND CHALLENGES
}

\begin{abstract}
Akhtar Sherin $^{1 \otimes}$
THIS ARTICLE MAY BE CITED AS: Sherin A. Preparedness and response of Pakistan for coronavirus disease 2019: gaps and challenges. Khyber Med Univ J 2020; I2(2):79-80. DOI: I 0.35845/kmuj.2020.20450.
\end{abstract}

E ver since the first case reported from Wuhan, China, the exponential rise in new cases of Coronavirus Disease 2019 (COVID-19) across the globe, led to the worst pandemic of $2 I^{\text {st }}$ century. According to World Health Organization (WHO), there were $7,355,98$ I confirmed cases of COVID- $\mid 9$ and $4|6,89|$ deaths till June $\mid 2$, 2020.' COVID-19 is not only a major global health crisis with limited knowledge about the dynamics of the disease, but is a serious threat to the global socioeconomic status. At present, there is no cure or vaccine available for COVID-19. The strategy of WHO is to guide all countries to slow down the COVID-19 transmission and to protect their health systems. ${ }^{2}$ WHO has already issued a strategic plan for preparedness and response regarding COVID-19.

In Pakistan, the first case of COVID-19 was confirmed on February 26, 2020 and currently there are 125,933 confirmed cases of COVID-19 (including 6,397 new cases during last 24 hours) and 2,463 deaths till June 12, 2020. ${ }^{4}$ Although the Government of Pakistan was able to draft a National Action Plan for COVID-19 in March 2020, ${ }^{5}$ and took initial positive steps as well but the major flaws in implementation strategy, resulted in failures at multiple stages. ${ }^{6}$ According to WHO report on June 9, 2020, Pakistan has level-2 ( $\leq 40 \%)$ preparedness capacity for COVID-19.

No doubt, that the COVID-19 pandemic is an extraordinary situation and even the world's leading health systems have faced difficulties in coping with the situation. However, looking at the preparedness, capacity of health system of Pakistan was not even ready to be challenged for such pandemic. Probably health ministry had not followed the WHO earlier guidelines issued in $2017^{8} \& 2018^{9}$ regarding influenza risk and impact management as well as capacity building for such pandemic response.

It was very likely for Pakistan to get the COVID-19 cases as it shared the borders with China \& Iran - countries with very high number of COVID-19 cases and deaths. Pakistan's first-line response of closing borders with China and Iran was a very positive step. Later on, travels restrictions were extended to all international \& national flights, train services and inter-city transport as well. Closing educational institutions, offices, markets and restrictions on religious congregations were the main steps taken by the government. However, overall response of political leadership can be labelled as "confused response". ${ }^{10}$ Federal and provincial governments were not on same page regarding complete lockdown, leading to partial and later on controversial "smart lock-down" due to severe economic pressure. Lack of public awareness, "infodemic" of incorrect information, myths, propaganda and conspiracy theories about COVID-19, mishandling the newly diagnosed patients or their families and dealing with dead bodies of COVID-19 patients led to an altered public response for COVID- 19. Government could neither convince the public about maintaining social distancing nor enforce the standard operational procedures suggested for easing the lockdown. This proved to be a disaster, leading to a surge of new cases across the country. WHO's Head of Mission in Pakistan, Dr Palitha Mahipala in a letter on June 07, 2020 criticised the decision and advised to re-impose the lockdown."

Preparedness for surveillance investigation and assessment of COVID19 cases was very low in Pakistan. Daily
I. Chief Editor, Khyber Medical University Journal and Professor of Medicine, Khyber Medical University Institute of Medical Sciences, Kohat, Pakistan. Email区:akhtarsherin@yahoo.com

testing capacity of Pakistan for COVID- 19 was $6584 / \mathrm{day}^{12}$ on April 07, 2020 and increased to $16414 /$ day $^{13}$ on April 28, 2020. However, with over six thousands new cases per day, testing capacity needs to be increased several folds. Another major area of concern is risk and severity assessment, health services provision and clinical management of severe cases. Government of Pakistan established several quarantine centers in major cities of Pakistan as well as near Pakistan-Iran \& Pakistan-Afghan borders.

Majority of COVID-19 patients with mild to moderate severity were managed effectively in all clinical settings. However, the major issue observed during the clinical management of severe COVID-I9 patients was lack of intensive care facilities across the Pakistan. Lack of trained human resources (e.g. intensivists and paramedics), shortage of appropriate medical devices like ventilators, interrupted supply of essential medicines including central oxygen supply, nonavailability of important investigations like D-Dimers, CT chest etc. in majority of health-care settings and absence of local guidelines for management of serious patients exposed the existing health-care services provision of Pakistan. Response of health-care providers was exemplary and despite lacking appropriate personal protective equipment served with dedication and professionalism. However a very large number of health-care providers contracted COVID-19 during service provision and unfortunately, a significant number of doctors, paramedics and nurses died due to COVID-19. This adversely affected the clinical management and recovery process of the COVID-I 9 patients.

Maintaining the essential services and monitoring of commodity prices is vital in such pandemic situations. Unfortunately, price hikes of essential drugs, petrol and flour crises and economic crises showed poor control and response of government during this critical time.

Overall, preparedness and response of Pakistan in anticipating, preventing, detecting, managing and controlling the COVID-1 9 outbreak was suboptimal. It is 
highly suggested that government authorities may revisit the national action plan for COVID-19 to identify the gaps and cope with the new challenges. Pakistan needs to increase the share of the nation's Gross Domestic Product on health spending not only to ensure excellence in clinical services but also to strengthen the public health system of Pakistan

\section{REFERENCES}

I. World Health Organization (WHO). WHO Coronavirus Disease (COVID19) Dashboard. Data last updated 2020/6/12. [Accessed on: June 12, 2020]. Available from URL: https://covid I9.who.int/.

2. World Health Organization (WHO). COVID-I 9 Strategy Update. 14 April 2020. [Accessed on: June 12, 2020]. Available from URL: https://www. who.int/publications/i/item/covid-19strategy-update---| 4-april-2020.

3. World Health Organization (WHO). 20 I 9 Novel Coronavirus (2019-nCoV): Strategic preparedness and response plan. Draft as of 3 February 2020. [Accessed on: June I2, 2020]. Available from URL: https://www.who.int/docs/defaultsource/coronaviruse/srp04022020.pdf.

4. Government of Pakistan. Coronavirus in Pakistan. June 12, 2020. [Accessed on: June 12, 2020]. Available from URL: http://covid.gov.pk/stats/ pakistan.

5. Government of Pakistan-Ministry of
National Health Services, Regulations \& Coordination. National Action Plan for Corona virus disease (COVID-19) Pakistan. [Accessed on: June 12, 2020]. Available from URL: https://www.nih.org.pk/wpcontent/uploads/2020/03/COVID 19-NAP-V2-13-March-2020.pdf

6. Javed B, Sarwer A, Soto EB, Mashwan Z-u-R. Is Pakistan's Response to Coronavirus (SARS-CoV-2) Adequate to Prevent an Outbreak? Front Med (Laussane) 2020;7:I58. DOI: 10.3389/fmed.2020.00I58.

7. World Health Organization (WHO). Covid- 19 strategic preparedness and response plan. Country Preparedness and Response Status for COVID- 19 as of 9 June 2020. [Accessed on: June II, 2020]. Available from URL: https://www.who.int/publications/i/it em/updated-country-preparednessand-response-status-for-covid-19-asof-9-june-2020.

8. World Health Organization (WHO). Pandemic influenza risk management: a WHO guide to inform \& harmonize national \& international pandemic preparedness and response. Geneva: WHO. 20I7. [Accessed on: June II, 2020]. Available from URL: http://www.who.int/influenza/prepar edness/pandemic/influenza_risk_man agement_update2017/en/.

9. World Health Organization (WHO). A checklist for pandemic influenza risk and impact management: building capacity for pandemic response. Geneva: World Health Organization
(WHO); 20I8. [Accessed on: June II 2020]. Available from URL: http://www.who.int/influenza/prepar edness/pandemic/PIRM_Checklist_u pdate2018.pdf.

10. Khattak D. Pakistan's Confused COVID-19 Response. The Diplomat. June 09, 2020. [Accessed on: June II, 2020]. Available from URL: https://thediplomat.com/2020/06/pak istans-confused-covid-19-response/.

II. Reuters. World News, June 10, 2020. WHO recommends Pakistan reimpose intermittent lockdowns as COVID-I9 cases rise sharply. [Accessed on: June II, 2020]. A vailable from URL: https://www.reuters.com/article/ushealth-coronavirus-pakistanwho/who-recommends-pakistanreimpose-intermittent-lockdownsas-covid-19-cases-rise-sharplyidUSKBN23G2Z].

12. Mirza Z. Pakistan plans to increase its daily testing capacity for \# coronavirus to 20000 in coming days. Currently it is $6584 /$ day. Tweet no. 276. Apr 7, 2020. [Accessed on: June II, 2020]. Available from URL: https://twitter. com/zfrmrza/status/ I 2475 | 33236 |4 031872

13. Government of Pakistan. Testing Capacity and Functional Labs in Pakistan COVIDI9 (April 28, 2020). [Accessed on: June II, 2020]. Available from URL: http://covid. gov.pk/facilities/Testing\%20Capacity \%20\&\%20Functional\%20Labs\%20 COVIDI9\%20VI.I.pdf.
CONFLICT OF INTEREST

Author declared no conflict of interest GRANT SUPPORT AND FINANCIAL DISCLOSURE NIL

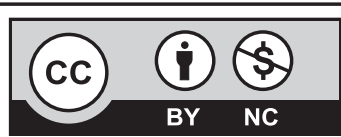

This is an Open Access article distributed under the terms of the Creative Commons Attribution-Non Commercial 2.0 Generic License.
KMUJ web address: www.kmuj.kmu.edu.pk

Email address: kmuj@kmu.edu.pk 